Article

\title{
Christian Churches and the Boko Haram Insurgency in Cameroon: Dilemmas and Responses
}

\author{
Lang Michael Kpughe \\ Department of History, Higher Teacher Training College, University of Bamenda, Bambili-Bamenda 39, \\ Cameroon; info@httcbambili.com
}

Received: 15 June 2017; Accepted: 1 August 2017; Published: 7 August 2017

\begin{abstract}
The spillover of the terrorist activities of Boko Haram, a Nigerian jihadi group, into Cameroon's north has resulted in security challenges and humanitarian activity opportunities for Christian churches. The insurgents have attacked and destroyed churches, abducted Christians, worsened Muslim-Christian relations, and caused a humanitarian crisis. These ensuing phenomena have adversely affected Christian churches in this region, triggering an aura of responses: coping strategies, humanitarian work among refugees, and inter-faith dialogue. These responses are predicated on Christianity's potential as a resource for peace, compassion, and love. In this study we emphasize the role of Christian churches in dealing with the Boko Haram insurgency. It opens with a presentation of the religious configuration of Cameroon, followed by a contextualization of Boko Haram insurgency in Cameroon's north. The paper further examines the brutality meted out on Christians and church property. The final section is an examination of the spiritual, humanitarian, and relief services provided by churches. The paper argues that although Christian churches have suffered at the hands of Boko Haram insurgents, they have engaged in various beneficial responses underpinned by the Christian values of peace and love.
\end{abstract}

Keywords: Cameroon; terrorism; religion; Islam; Boko Haram; Christian Churches; peace

\section{Introduction}

There is a consensus in the available literature that all religions have within the practices ensuing from their foundational beliefs both violent and peaceful tendencies (Bercovitch and Kadayifci-Orellana 2009; Chapman 2007; Fox 1999). In well-established global religions such as Christianity and Islam, there exist ideologies and doctrines that are so diverse and complex that justification for both violence and peace can be found within their traditions. As such, virtually all religions have at different times and places been associated either with conflict or peace. In Terror in the Mind of God, Mark Juergensmeyer (Juergensmeyer 2003) argues that all global religions have had a violent perspective. Clearly, therefore, religion, violence, and peace have been companions throughout human history. However, for some time now, militant Islamism in the hands of minority extremists in the name of Islam has grown, with no continent left untouched. This Islamic militancy, as should be expected, has left the affected people (Muslims and non-Muslims) shocked, angry, and uncomprehending. As Esposito notes, Islamic terrorism builds on the fact that Islam emphasizes action given that Muslims are enjoined "to struggle (jihad) to implement their belief, to lead a good life, to defend religion, to contribute to the development of a just Islamic society throughout the world" (Esposito 2002, p. 5). In this present context of Muslim extremism and ensuing terrorism, the word jihad is used by terrorist movements such as Al-Qaeda, Al-Shabaab, Boko Haram, Islamic State, and the like to legitimise their causes and motivate their followers.

With its historical roots traced to 2002 and fed by frustration resulting from political, economic, social, and religious issues, the Boko Haram, after its early violence in 2003-2004 in Yobe State, 
became more of a threat from 2009, with civilian casualties, fear, and material damage heightening tremendously. By the time the terrorist acts of the sect began spilling over into neighbouring Cameroon, its scope of operation had expanded. Given that the terrorist movement is partly couched in religious terms, as its leaders claim, Christians and Muslims were targeted in churches and mosques through suicide bombings, direct attacks by armed insurgents, kidnappings, and the like. Indeed, its declared religious agenda was and is to establish a pure Islamic state across West Africa governed under the Sharia Law (Asfura-Heim and MaQuaid 2015; Walker 2012). This is indicative that Christianity together with its faithful and property is under attack, though most of the sect's victims have been Muslims. It is important to stress that the victimization of Christian organizations by perpetrators of terrorism is not a new phenomenon. In fact, since the spillover of Boko Haram into Cameroon, churches, their clergy, and their faithful have been targeted through suicide bombings, gun attacks, kidnappings, rape, and the like.

This openly declared religious agenda, along with the growth of the group's violence in Cameroon as in Nigeria, Niger, and Chad, was an issue that cannot be allowed to continue unperturbed. Without doubt, the Boko Haram insurgency was and is threatening Cameroon's peace and requires a committed engagement in its management. As the Cameroon government fully embraced its responsibility of protecting the citizenry by deploying the military to curb the insurgence, it soon became obvious that the military approach was hugely inappropriate, given that the group has no clear command structure or a known regular force. Consequently, a holistic, proactive peace approach became necessary, and the greatly affected Christian Church was required to come on board. In fact, tapping Christianity's potential to respond to the Boko Haram insurgency became indispensable. This is perhaps why in Christian Response to Islam, Islamism and 'Islamic Terrorism', Chapman (2007) calls for a cautious Christian response to the terror orchestrated in the name of Islam. Boko Haram's multiple assaults on Christian life and property in the north of Cameroon quickly served as a basis for Catholic, Protestant, and Pentecostal churches to consider the vocation of peace as a response.

There is consensus in the literature that the Christian, just like other religions, is replete with resources that may influence the effectiveness of any conflict management and resolution effort. So far, however, scholars have either missed or overlooked churches' response to the ongoing Boko Haram rampage despite the recognition of religion as a "viable tool for conflict transformation" (Kadayifci-Orellana 2013, p. 149). Instead, the development and motivations of the sect have received much scholarly attention. Recently, a handful of scholars have begun, hesitantly, to pay attention to churches' response to the insurgency. Ahmed-Hameed (2015) has broadly examined the role of interfaith dialogue in checking interreligious conflict in northern Nigeria. He blames religion for exacerbating conflicts, stressing that religions' response to such crises is still in its infancy. Kah (2014) also notes the persistence of religiously fueled conflicts in Central African Republic, partly attributing it to unyielding interreligious peacebuilding efforts. This paper takes its cue from these studies to contribute to the scholarship on churches' role in conflict transformation. It situates the encounter between the Boko Haram insurgency and churches in the broader discourse. Essentially, what I offer here is a preliminary attempt at a new perspective of Boko Haram violence-one that rescues the churches' response from academic neglect. The paper examines how the Boko Haram insurgency has affected Christian churches in Cameroon, along with their responses to that intolerance.

\section{Politico-Religious Makeup of Cameroon}

Located in Central African sub region, an environment plagued by insurgency, Cameroon was annexed and governed by Germany between 1884 and 1916. The territory was eventually partitioned and placed under British and French administrations first as mandates of the League of Nations and later as trust territories of the United Nations. In October 1961, the southern portion of British Cameroon reunified with French Cameroon (which had earlier gained independence in 1960) to constitute the modern Cameroon state (Fanso 1989; Ngoh 1996). The young state was governed by Ahmadou Ahidjo from 1961 to 1982 and since then by Paul Biya. Ahidjo's nation-building efforts 
shifted Cameroon from a multiparty to a one-party system in 1966 and from a federal to a unitary system in 1972. Though described by critics as a matchless dictator, considering the ordered arbitrary arrests, torture, and murders meted out on the citizenry to increase control through fear, Ahidjo's tenure was marked by social and economic growth, with ensuing improved wellbeing.

The euphoric transition to Paul Biya in 1982 following Ahidjo's surprising resignation was soon marred by a succession of ugly events: the Biya-Ahidjo rift, the abortive coup of 1984, the economic crisis from 1986, demand for liberalization characterized by unrest across the country, Anglophone nationalism, and state-sponsored brutality. There was recourse to reforms beginning with the birth of the Cameroon People's Democratic Movement (CPDM) in 1985 as a replacement for the Cameroon National Union (CNU), a return to multiparty politics in 1990, the 1996 constitutional reforms, and chequered democratization efforts. Some of these events and their ensuing reforms play into the responses to the brutalities of Boko Haram. Building on the presidential system that has enabled him to gain the appellation "Father of the Nation," just like his predecessor, Paul Biya whipped up national sentiments when he declared war on Boko Haram and deployed his CPDM political weapon in an effort to mobilize the support of the population, without distinction, in dealing with the insurgency.

Cameroon's religious configuration, in the north specifically, has a bearing on the Boko Haram insurgency as well as efforts at dealing with its heinous atrocities. Since Cameroon's crafting by the Germans in the last quarter of the nineteenth century, Cameroon has evolved into a highly religious country. Long before the colonial encounter, the population was a blend of numerous ethnic entities, whose indigenous religions differed significantly. Each ethnic group had its indigenous religion whose observance was almost communal and absolute. These indigenous religions had cross-cutting features: prayer, rituals, sacrifice, and the belief in a Supreme Being whose appellation was as varied as the ethnic groups. These religious practices and beliefs permeated all areas of life.

The imposition of Islam in the northern region and the beginning of Christian missionary work in the south in the first half of the nineteenth century altered the almost homogenous religious configuration of Cameroon. The jihadi movement of Modibbo Adama launched Islam's ascendancy in the northern region, dividing the people between followers of indigenous religion and Islam (Lang 2015, p. 61). In the southern part, from the 1840s, Western Christian mission agencies (London Baptist Mission, Basel Mission, American Presbyterian Mission, Pallottine Fathers, Mill Hill Fathers, Holy Ghost Fathers, and Paris Evangelical Mission) began mission work, initially in the coastal areas. This caused Cameroon's religious landscape to be shaped into what Adama labels as the Christian South and the Muslim North (Adama 2006, p. 47). By the attainment of independence in 1960-1961, these religions were no longer restricted to these geographical zones. Islam and Christianity had advanced southward and northward, respectively, as the expansionist desires of Muslim clerics and Christian missionaries culminated in the planting of Christianity and Islam throughout Cameroon.

The parochial nature that characterized the Christian tradition is worth highlighting. During the colonial period, the sole Christian traditions were Catholicism and Protestantism that were largely established along regional and ethnic divides. Catholic missionary boards in both French and British Cameroon produced the Roman Catholic Church (RCC) of Cameroon, which today dominates the Christian landscape. The decision-making body of the church is the National Episcopal Conference of Cameroon, currently having as President Mrg Samuel Kleder, Archbishop of Douala Archdiocese. The Conference brings together bishops from across the territory to discuss issues affecting the church (Messina and Slageren 2005), amongst them Boko Haram. The mainline Protestant churches that emerged from the ecclesiastical mould of mission agencies include Presbyterian Church in Cameroon (PCC), having as Moderator Right Reverend Samuel Fonki, Cameroon Baptist Convention (CBC) under the leadership of Joe Chebonkeng Kalabubsi, Eglise Evangélique du Cameroun, headed by Reverend Jean Samuel Hendje Toya, and Eglise Presbytérienne Camerounaise, whose Moderator is Reverend Song Jean Emile Vincent. All these churches are planted in Cameroon's north and have been affected in various ways by Boko Haram brutality. Mainstream Protestant churches have constituted themselves into 
the Council of Protestant Churches of Cameroon (CPCC), headed by Reverend Goyek Daga Robert, through which they deal with the insurgency in the north.

Since independence, as Akoko confirms, Pentecostal churches have emerged and are increasingly challenging the Catholic and Mainstream Protestant hegemony in the religious sphere (Akoko 2007, p. 192). These churches now have a heavy presence in the north, with high visibility in the public place. As elsewhere in the country, this growth in Pentecostalism coincides with general impoverishment that is exacerbated by a long-dragging economic crisis. Unlike in neighbouring Nigeria where Pentecostal churches have an umbrella association (the Pentecostal Fellowship of Nigeria) through which they engage with the society, such churches in Cameroon act independently. So, while Catholics and mainstream Protestants have umbrella organizations through which they respond to Boko Haram brutality, Pentecostals, due to the absence of such an organizational structure, deal with the insurgency in an uncoordinated manner.

Cameroon has become more multireligious, even though the country is still predominantly Christian (69\%). The latter is divided between Catholics (38\%), mainstream Protestants $(26 \%)$, and Pentecostals (4\%). The Muslims represent $21 \%$, and followers of indigenous religions, arguably, $5 \%$. This diversity is also a defining feature of the religious makeup of the northern region, though the dominant Fulani ethnic group is predominantly Muslim. In general, the population in this region is fairly evenly divided among Muslims, Christians, and followers of indigenous religions. Within northern Cameroon, there are variations in the presence of Christianity. Catholics, mainstream Protestants, and Pentecostals are heavily present in major towns like Ngaoundere, Garoua, and Maroua, with $\mathrm{dwindling}$ numbers in the interior. The reality is that although Islam is firmly established in the three northern administrative regions (Adamawa, North, and Far North), there are Christian communities scattered here and there throughout Cameroon's north (Goyek 2012, p. 102). As they reach out to people of other faiths in the quest for converts, encounters and tensions between Christians and Muslims are intensified. Christians faced difficult moments at the hands of some Muslim leaders who were hostile to their faith. (Boukar 2014, p. 39). This makes northern Cameroon, a region currently plagued by Boko Haram brutality, a space of negotiation and confrontation in the encounter between Christianity and Islam, and within Christianity. This hinged on misjudgment and Muslims' conversion to Christianity, a strange phenomenon in Muslim milieus of the region. These encounters and ensuing negotiations have been intensified by the Boko Haram insurgency, whose historical contextualization is necessary.

\section{Contextualizing Boko Haram Militant Islamism in Cameroon}

The militant Islamism of Boko Haram has connections with the jihad tradition that characterized the Islamization of West and Central African societies in the nineteenth century. The Sokoto Caliphate and its affiliate, the Adamawa Emirate, were products of the Islamic revolutions led by Muslim reformers such as Uthman Dan Fodio and Modibbo Adama (Adama 2010). These Islamically legitimated states covered parts of modern-day Nigeria, Cameroon, Chad, and Niger. This jihadi precedence serves as a lens for appreciating the militant Islamism currently roiling some West and Central African states. In fact, the development of Boko Haram cannot be dissociated from the long traditions of militant jihad in West and Central Africa. Boko Haram and the early jihad movements had an exclusivist approach. This exclusivism demands that Muslims choose between Islam and what Thurston describes as "a set of allegedly anti-Islamic practices" (Thurston 2016, p. 5). Although both the early jihadi movements and Boko Haram are religiously motivated and employ the use of violence, they differ in certain respects. In the thinking of Voll, Boko Haram's militant Islamism is not just a "continuation of older religious militancy," but is also a "product of contemporary Muslim radical beliefs identified as Salafism" (Voll 2015, p. 1185). While Dan Fodio and Adama were Sufists, Boko Haram is a Salafi-jihadi movement. Boko Haram is opposed to the pollution of "pure" Islam, initially directing its violence against other Muslim groups, just like the nineteenth century jihadi movements. Sketching the development of jihadi movements in Northern Nigeria, Murray 
Last (Last 2014) notes a shift from Sufi orders to a Salafi one, with violence against Muslims and non-Muslims as their convergence point. To this should be added the modern societal mutations to which Boko Haram is opposed. Hence, in spite drawing inspiration from the jihadi legacy of Uthman Dan Fodio, Boko Haram, unlike nineteenth century reformist movements, represents the modern dimension of religious terrorism, at the centre of which is Salafi doctrinal ideology.

The Boko Haram insurgency, in some respect, is indicative of the doctrinal justification of violence, tenable or not, as a defining feature of Islam's historical development. Although the goals of the militant group are undeniably ambiguous, the violence and bloodshed it perpetuates make clear the complex interactions between the Muslim extremist group and conflict (Azumah 2014, p. 4; Blanchard 2016). In the northern part of Cameroon, the relationship between Islam and violence is not unique to the current Boko Haram insurgency-it has existed since the nineteenth century jihad of Modibo Adama. As a matter of fact, the jihadist legacy in the region dates to the early part of this century, when Adama led a Fulani insurgency against numerous Muslim and non-Muslim communities. This is a factor not to be missed when contextualizing the spillover of Boko Haram militancy into this Muslim-dominated part of Cameroon. In fact, the nineteenth century jihad amounted to the birth of the Adamawa Emirate, a Muslim theocratic state that was governed along Islamic lines. This marked the beginning of the dominance of the Islamic faith in this region and represented a precedence of its functioning as an identity-forming mechanism with the capacity to construct and mobilize individuals and groups, both to violence as well as to peace. The nineteenth century jihad was the beginning of a period of pacifism, making the potential of violence a part of Islam's symbolic system, no matter its proclamation of peace and nonviolence. Wellman provides a working definition of religion that among other things stresses that "The symbolic and social boundaries of religion mobilize individual and group identity, and create conflict and, more rarely, violence within and between groups" (Wellman 2007, p. 4).

Seen this way, it is clear that fundamentalism whose outcome is violence became a defining factor of Islam in Cameroon and across West and Central Africa in places where the jihads were successful. Since then, religiously inspired violence has characterized the historical development of Islam in northern Cameroon. In pre-colonial north Cameroon and Nigeria, forceful conversion to Islam dragged on up to the eve of colonialism. It was a period when followers of Traditional Religion were targets of Islamic violence. As Njeuma observes, Fulbe Muslims insisted that Islam offered a superior God to whom all must submit, and that obedience to Allah's Messenger was obligatory (Njeuma 2000, p. 12). Thus, the Jihad marked the first major religious conflict in pre-colonial Cameroon, with whole communities suffering defeat and forceful conversion to an exclusivist version of Islam (Njeuma 1978, p. 8).

The Adamawa Emirate that accrued from this jihad came under German rule in the 1890s. The Germans maintained the old order through indirect rule and gave official recognition and protection to Islam's influence in the north. This served as a barrier for Christian missionaries to extend their activities into the north. The French who succeeded the Germans after the First World War hesitatingly allowed Christian missionaries to plant Christianity in the area amid Muslim suspicion. Since then, the religious landscape of the region has been characterized by intolerance and divisiveness (Schilder 1993, p. 45). In fact, the path to Muslim-Christian cohabitation in north Cameroon is littered with intolerance, given that both faiths have a universal message. Without doubt, both religions have their accepted dogmas that followers must accept without question. With this proneness to religious violence running its course in north Cameroon, the global phenomenon of modern Islamic movements emerged as a driving force behind the resurgence of Islam (Esposito 2002, p. 84).

This, among other things, was fed by Muslims' rich legacy of traditions that require them to reform their societies in every age (Fonge 2015, p. 24). The nineteenth century jihads in West Africa should be understood in this context. Around the close of the twentieth century, this reform came in transformed ways marked by the proliferation of terrorist Islamic movements. Boko Haram is one of such movements, and Nigeria, its birth place, has a proven fertile ground for such religious violence. According to Adesoji, the group's gradual rise represented an attempt by Islamic conservative elements at imposing a variant of "Islamic religious ideology" (Adesoji 2010, p. 95). From its Nigerian base, 
it strove to create an Islamic state in West Africa. Its leaders hoped to exploit the religious sensitivity of Muslims in Nigeria, Cameroon, Chad, and Niger, which in Onuoha's thinking provided fertile ground for the breeding of such extremist groups (Onuoha 2014). Thus, the spillover of Boko Haram into neighbouring Cameroon was expected.

With its radical Islamic ideology, the group spilled into Cameroon's north, a region with a pluralist religious configuration and some precedence of intolerance among opposing and competing faith traditions. Since 2013, it has wrecked immense havoc by sponsoring kidnappings, suicide bombings, gun attacks, and the destruction of churches and mosques, with cataclysmic consequences for Muslims and non-Muslims. These dilemmas that threaten the survival of Christianity in Cameroon's north necessitated churches' response to Boko Haram violence. In spite of its political and economic goals, Boko Haram can be described as an Islamic sect that believes corrupt, false Muslims and Christians control areas where reformed Islam is supposed to thrive. Originally, the group calls itself ama'atu Ahlis Sunnar Lidda'awati Wal-Jihad, which broadly translates to "people committed to the propagation of the Prophet's teachings and jihad." In January 2012, Abubakar Shakau appeared in a video posted on You Tube in which he stated that "Boko Haram is at war with Christians." (Mark 2012; Ogochukwu 2013, p. 5). This has made Christians in north Cameroon targets of the Islamic sect.

\section{Boko Haram: A Dilemma for the Christian Church}

It is very difficult not to accept that one of the motivations of the Boko Haram insurgents in Cameroon was and is theological. Writing for the Oxford Research Group, Reeve notes that the Salafist commitment of Boko Haram leaders is real (Reeve 2014, p. 3). Their attacks on Christians and church property could be indicative that the country is on the brink of a religious war. Earlier in 2012, Shakau told Christians that "The religion of Christianity you are practicing is not a religion of God-it is paganism ... We are trying to coerce you to embrace Islam, because that is what God instructed us to do" (Shekau 2012). In its numerous operations in the north, the group has always left behind sad stories and frightening scenes of destruction, death, and kidnappings among Christians, but mostly Muslims, notably politicians and hereditary rulers. For close to three years now, Boko Haram insurgents have orchestrated indiscriminate terrorist violence on the Christian church.

The group began kidnapping Christian missionaries, making it clear that the further Christianization of north Cameroon would be a difficult task. In November 2013, a French priest, Georges Vandenbeusch, was abducted by armed militants of this sect. In April 2014, more abductions followed when two Italian priests and a Canadian nun were kidnapped from a church facility in Tchere (Guibbaud 2014, p. 2). In the town of Mora, Catholic and Protestant Christian leaders were forced by surprised attacks to cancel Sunday services and other important religious events such as Christmas and New Year vigils in December 2014. In fact, Christian places of worship in the town were closed in the last months of 2014 when the asymmetric violence heightened. The General Secretary of the German-based Baptist Mission Agency, Christoph Haus, reported to the Baptist World Alliance that Christians and missionaries had been kidnapped by the group. He explained how the Islamists attacked and destroyed some Baptist churches at the border with Nigeria. The brutality caused the German-based Baptist Mission Agency to evacuate its missionaries from Cameroon' north.

In 2014, Christian populations were particularly targeted. This is particularly true of the village of Cherif Moussary, where a church was ransacked and the residence of the pastor burned down. Many Christian families were stripped of their property, according to a World Watch Monitor report (World Watch Monitor 2015). There were similar acts of desecration in Mouldougoua and Assighassia. The latter was occupied in August for days by Boko Haram militants before they wereousted by the army. Regrettably, Zerubbabel Tchamaya and Samuel Lada, elders of this church, were beheaded during the occupation. In Djibrilli village, a pastor was kidnapped, threatened, and asked about his faith by militants before being released the following day (Djadi 2014). Strategically, the assailants attacked in the night, when the army was no longer patrolling in the villages. They entered 
the houses of Christians and stripped them of their property. In most occasions, churches were ransacked and valuables such as musical instruments were destroyed or taken away by the extremists.

On 28 July 2015, members of Boko Haram attacked two villages in northern Cameroon, burning down a Catholic church and beheading three Christians. Later, in October 2015, armed gunmen attacked another church in a village outside Mora, killing eight Christians, destroying the church building, and causing many Christians to flee. The recent approach adopted by Boko Haram is that of sending suicide bombers to destroy churches and kill Christians. This demonstrates the harassment, intimidation, and violence that Christians face at the hands of these extremists in the parts of north Cameroon affected by the insurgence. The brutality has caused some of the churches to pull out their missionaries from these areas. The extremism is also demonstrative of why some Christians have fled from the land of their birth, taking refuge in other towns and in refugee camps. In addition, some Christians of southern extraction who were posted to work in the north are doing everything possible to be transferred to other parts of the country.

Worth noting is the fact that Boko Haram extremism against Christians and Muslims is a clear transgression of the religious freedom clauses enshrined in the constitution of Cameroon. Since 2013, many Christians have been denied the core principle of freedom of worship in some parts of north Cameroon. Although statistics are hard to come by, the Christian population in areas frequently attacked by the insurgents such as Fotokol, Mora, and the like has rolled back. While some have been killed and abducted, others have escaped to safe zones. The pressure is even higher especially on Christians from a Muslim background who have chosen to become Christians. Any objective analysis of Boko Haram insurgency would recognize the anti-Christian dimension of the jihadi group. The British-based Christian Institute blamed Boko Haram for killing nearly 4000 people in 2014, some of whom were Christians (Christian Institute 2015).Without doubt, there is a heightened level of fear for Christians in Cameroon's north, especially close to the border with Nigeria. This unprecedented extremism has created fear, caused deaths and property loss, and has heightened suspicion and intolerance between Christians and Muslims. These dilemmas, taken together, necessitated churches' response in multiple fronts.

\section{Christian Responses to the Boko Haram Extremism}

Down the centuries, as Azumah observes, Christians have had a polarized response to Islamic extremism (Azumah 2010, p. 83). While some Christians have opted for a tough response, others have preferred a soft or conciliatory one. Broadly, Christian responses to Islam have changed over time, given that the medieval period was marked by a confrontational Christian anti-Islamic polemic, as opposed to the more conciliatory and open mechanisms of the contemporary period (Kate 1997, p. 6). In the wake of the spillover of Boko Haram insurgency into Cameroon, churches (Catholic, Protestant, and Pentecostal) have responded in various ways. As noted earlier, the extremism came at a time when the north's religious landscape was already on the path to radicalism. This section critiques how the Christian community in Cameroon has responded to the Boko Haram brutality.

In Cameroon, the current Islamic militancy has emerged as a determinant factor for Christian responses to Islam. This, as already noted, accrues from the trauma of the Boko Haram attacks along with the huge psychological and evangelical impact on the Christian church. Initially, the operations of the Boko Haram was not given a serious attention by the Christian community, despite their counterparts in Nigeria already responding to the violence. This is premised on the assumption that Boko Haram, in spite its extremism against Christians, was a Nigerian sect, with nothing to do with Cameroon. This flawed assumption caused the Christian clergy to do nothing to monitor the dynamics of the extremism or locate early warning signs to foresee its spillover into Cameroon. In 2013 and 2014, following the first abductions, the Christian faithful in the north came to understand that the sect was a huge threat to their faith tradition. Such consciousness caused Catholic, Protestant, and Pentecostal church leaders to organize prayers calling on God to facilitate the release of the abducted clerics. The Cameroon National Episcopal Conference went beyond prayers by issuing a statement 
urging Boko Haram to enter into dialogue with the Cameroon government for the release of Catholic clerics. The retired Archbishop of Douala, Cardinal Tumi, further insisted on such dialogue, observing that, "Our message to those who still hold our brothers in captivity is that they should release them and hold dialogue."

Christians seem to have quickly understood that while Boko Haram Islamist insurgents use Qur'anic verses calling for violence as a theological justification for their terrorist acts, many orthodox Muslims do not agree with this way of interpreting the Qur'an. If one can go by messages from Catholic and Protestant clergy, it is evident that there is a consensus call for Christians to be careful on their judgments about the Qur'an. Christian leaders have not yielded to the temptation of telling Muslims how they should interpret the Qur'an and have avoided associating all Cameroonian Muslims with the Boko Haram radical religious ideology. Largely, the Christian community sees Islam as a religion with a potential to guarantee peace, in spite its use by Boko Haram leaders to justify the terror running its course in Cameroon's north. These messages have made Christians recognize that a majority of Muslims in Cameroon are not associated with ongoing militant Islam. Though under attack, Christians have not approved declarations that the insurgents fight and kill others in defence of Islam. Cameroonian Muslims, with the exception of the minority extremists, totally reject the use of Qur'anic verses to justify violence in the name of Islam.

In his induction sermon as Moderator of the Presbyterian Church in Cameroon, Right Reverend Samuel Forba Fonki called on Christians to partner with the government to restore the peace and sovereignty threatened by the Boko Haram sect (Rt. Rev. Samuel Forba Fonki 2015, p. 6). Cameroonian Christians have manifested the willingness to support those Muslims who are under attack because they challenge the harsher Islamist interpretations of the Qur'an. In numerous ways, Christians have sympathized with the orthodox Muslim community while denouncing radicals. Writing for L'Effort Camerounais, Fr Gerald Nyuykongmo Jumbam describes Boko Haram as an "agent of terror that kills without conscience and beat, bomb and lynch unarmed civilians in the name of religion" (Jumbam 2014).

On the humanitarian front, Nigerian and Cameroonian churches are engaged in cross-border cooperation to address the refugee crisis triggered by the insurgency. The Minawao refugee camp, which hosts thousands of displaced persons, has received assistance from Christian churches. In March 2015, the National Episcopal conferences of Nigeria and Cameroon entered a partnership intended to assist refugees in this camp. Since then, Catholic Church officials in Cameroon have been receiving and managing assistance from the National Episcopal Conference of Nigeria destined for Nigerians who have fled to Cameroon (Crossmap Christian News 2015). The Council of Protestant Churches in Cameroon (CPCC) runs food programmes in the Minawao camp, which is host to over 6000 refugees. In the Far North Region, the CPCC put in place a Crisis Committee in an effort to better handle the influx of Nigerian refugees. Chaired by Rev. Samuel Heteck, the Committee mobilized funds and visited the refugee camps with emergency needs capable of improving the livelihood of the displaced people. On 19 October 2015, fundraising and voluntary donation services were held in all Protestant churches in Cameroon (Crossmap Christian News 2015). Broadly, the churches pay attention to the spiritual, physical, financial, and material needs of the refugees by ministering to them and offering food, shelter and medicines.

Regarding the spiritual domain, Christian leaders have offered prayers and invoked instructive Christian texts at critical moments whenever there was an attack. In July 2015 for instance, the Catholic Church held a Prayer for Peace Service across the country. While presiding over this service in Douala, the President of the Cameroon Episcopal Conference, Archbishop Samuel Kleda, called on God to bless Cameroon with peace in these words: "We want to entrust Cameroon as well as all other countries in war to the Lord. The insecurity raging on our borders, in particular those with Nigeria, has created a psychosis in our population. In these situations, you must put yourself in the hands of the Almighty."

Christian leaders also responded to Boko Haram terrorist activities by initiating interfaith dialogue and collaborative engagement between Christians and Muslims. They did so, fearing that northern 
Cameroon would otherwise be exposed to sectarian violence. Christian leaders initially intended to break the cycle of revenge by preaching the gospel of forgiveness. Spiritual support was provided to the affected Christians. Later, the Christian clergy acknowledged the need to work together with Muslims. Consequently, various interreligious meetings and conferences were organized on the subject of Boko Haram by the Cameroonians Association for Interreligious Dialogue. Its gatherings, heavily attended by Christians and Muslims, are mostly occasional, intervening only when there is a threat to religious harmony (Goyek 2012, p. 102).The CPCC also organized several ecumenical services intended to enhance the cohabitation of religions in Cameroon, a preemptive measure for a radical response from targeted Christians. In April 2014 for instance, about 40 Christian and Muslim leaders met to promote a culture of peace and tolerance between different religious communities, and this led to a Youth Forum on 7 August in Maroua. Under the theme "Young Christians and Muslims together for peace and development," it allowed local authorities to call young people to be "an agent of intelligence" and to report any suspect activity. In their closing statement, Christian and Muslim youths took the commitment "to promote religious tolerance, to not give in to the bait of kidnappers and to remain faithful to the ideals of the Republic" (Djadi 2014).

The intensification of attacks by the Islamists and ensuing fears of the deterioration of Christian-Muslim relations caused religious leaders to organize an interfaith conference in the town of Mora on 21 January 2016 with the theme "Living in Peace in the Sight of God." Aimed at promoting tolerance and peace in such a diversified religious landscape, the conference was co-chaired by the Sultan of Wandala, Boukar Alhaji Yerima Brahim; Rev. Gregory Cador, Episcopal Vicar of Mora; and Rev. Samuel Heteck, President of the northern Cameroon branch of the CPCC (World Watch Monitor 2015). Apart from denouncing the violence, the Sultan of Wandala saw the conference as an opportunity for Muslims and Christians to look in the same direction as a means of checking religiously inspired terrorism. Overall, Muslim and Christian leaders resolved to persevere in their role as educators by promising to preach love and brotherhood within families, communities, and places of worship.

This interfaith dialogue has rolled back mutual misjudgment and mistrust, thus encouraging collaborative engagements. It is thanks to the dialogue that Christians, especially Protestants, have not associated Islam with the Boko Haram violence. The potential of a religious conflict in Cameroon's north has been checked by minimizing the possibility of Cameroonians' adherence to Boko Haram. The dialogue, as noted by some Muslim and Christian informants, has allowed Christians to better understand Islam, and Muslims to have a deep understanding of Christianity. Though targeted, the Christian faithful have not yielded to the temptation of resorting to Christian Zionism as a response. This has so far aided the management of the terrorist crisis, since it has prevented retaliatory attacks from the affected Christians in the north. Christian leaders have therefore succeeded in preventing the emergence of a militant Christianity in Cameroon in the wake of the Boko Haram insurgency. This is different from the ongoing Christian anti-balaka reprisal attacks against Muslims in the Central African Republic due to the lack of interreligious dialogue that could have checked the Muslim ex-Seleka campaign at infancy (Kah 2016).

In contrast to the Central African Republic, dialogue between Christians and Muslims in Cameroon has avoided sectarianism, thus providing an enabling environment for joint action by followers of both faith traditions. They work together in local vigilantee groups set up by traditional and government officials to check surprise attacks by Boko Haram insurgents. They can be found at road junctions, market squares, streets, bus stations, and outside churches and mosques, ensuring security. At such sites, like in Kolofata, Amchide, and Maroua, it is common to find a Muslim praying next to a Christian. Confidence Ngam Chia, a returnee Baptist Christian and civil servant from Maroua, lived these joint engagements which, according to him, are the result of Christian-Muslim dialogue. In Kolofata, as observed by Paul Sakava, Muslim youths distributed donations from churches to the afflicted population, often at great risk. When interviewed, Reverend Father Arnould Kwang noted that dialogue was a significant factor in shaping the motivations of these Christians and Muslims. 
This joint outreach notwithstanding, not all churches participate in the dialogue, notably Pentecostals who are yet to join the Cameroonians Association for Interreligious Dialogue. Pentecostal churches have rather chosen the path of personal action, mostly limiting their response to the spiritual realm. However, their charismatic and radical brand of Christianity may be a raw material for Christian extremism. In its 2015 report, the International Crisis Group (International Crisis Group 2015) notes how Pentecostal Christian groups represent a new dimension in religious fundamentalism in contemporary Cameroon. Pentecostals' blanket association of Muslims with the radical Boko Haram ideology sometimes carried the explicit sanction of some Pentecostal church leaders in that region. Such leaders may reflect a negative attitude toward Islam, just like Boko Haram. Already, their biblical literalism, which motivates religious intolerance, is serving as an obstacle to the response to the violence orchestrated by Boko Haram. However, the latter is equally demonized by some Pentecostal leaders through teachings. To them, Boko Haram's extremist ideology lacks broad-base support from majority Muslims. Evidently, Pentecostals lack a communal perception and understanding of Boko Haram, and are so far unable to put forth a synergized response to the insurgency. However, the fact that Pentecostalism generally encounters mainline churches and Islam in Cameroon's north with flexibility, as Dronen (2013) notes, is evidence that extremists are in the minority.

Churches' responses through interreligious dialogue in Cameroon's north, though unique, share similarities with what is happening in next door Nigeria and even beyond. The transnationalization of Boko Haram and the ensuing displacement of people have occasioned cross-border cooperation between Nigerian and Cameroonian churches. In both countries, there is recourse to interfaith dialogue to understand and address insurgency. However, while Nigerian Pentecostals are fully associated with dialogue and engagement structures, their Cameroonian counterparts remain hesitant, perhaps due to lack of coordination. By responding to Boko Haram violence through prayer, humanitarian initiatives, and interreligious engagement, Cameroonian churches have manifested Christianity's conflict transformation potential.

\section{Conclusions}

The purpose of this study was to examine how the Boko Haram insurgency has affected Christian churches in Cameroon along with their responses to intolerance. The study has established that Christian churches have suffered at the hands of Boko Haram insurgents, causing them to engage in adaptive responses which, to some degree, amount to defective peacebuilding efforts. The churches have dialogued and engaged with Islam, provided humanitarian assistance to refugees, and reduced the imminence of interreligious conflict. To improve and sustain this response, mainstream churches need to engage with the reluctant Pentecostals, considering that there can be no peace in the region without understanding and peace among faith traditions. This is possible only if there is broader and genuine dialogue. This requires the pursuance of a holistic approach involving all Christian churches. While responding to the humanitarian crisis provoked by the terror, the Christian clergy need to prevent the possible radicalization of their faithful in north Cameroon and the rest of the country. In doing this, they should build on Christian peace values and should try to understand the impact of the insurgency upon their Christians. This is because persistent attacks on Christians can result in psychological implications capable of pushing them to opt for a militant response to the Islamist violence orchestrated by a radical few, in the example of the ongoing Christian-Muslim sectarian conflict in Central African Republic.

Acknowledgments: The author thanks the reviewers for their thoughtful comments, constructive feedback, and suggestions that significantly improved the quality of the paper.

Conflicts of Interest: The author declares no conflict of interest. 


\section{References}

Adama, Hamadou. 2010. La Mosquée au Cameroun: Espace Public ou Espace Privé? L'Anthropologue Africain 17: 41-62.

Adama, Hamadou. 2006. Islam and the State in Cameroon: Between Tension and Accommodation. In Local Practices, Global Controversies: Islam in Sub-Saharan African Contexts. Edited by Kamari Maxine Clarke. Yale: The MacMillan Centre Working Paper Series, pp. 25-44.

Adesoji, Abimbola. 2010. The Boko Haram Uprising and Islamic Revivalism in Nigeria. Africa Spectrum 2: 95-108. Ahmed-Hameed, Aliyu. 2015. Interfaith Dialogue: Preventing Extremism and Interreligious Conflict in Northern Nigeria. International Journal of Humanities and Social Science Invention 4: 82-89.

Akoko, Robert Mbe. 2007. Ask and You Shall be Given: Pentecostalism and the Economic Crisis in Cameroon. Leiden: African Studies Collection Series, African Studies Centre.

Asfura-Heim, Patricio, and Julia MaQuaid. 2015. Diagnosing the Boko Haram Conflict: Grievances, Motivations, and Institutional Resilience in Northeast Nigeria. CNA Occasional Paper; Fort Belvoir, VA, USA: Defense Technical Information Center. Available online: www.dtic.mil (accessed on 8 June 2017).

Azumah, John. 2010. Christian Responses to Islam: A Struggle for the Soul of Christianity. Church and Society in Asia Today 13: 83-94.

Azumah, John. 2014. Responding to the Challenge of Boko Haram. Lausanne Global Analysis 3: 4-9.

Bercovitch, Jacob, and Ayse S. Kadayifci-Orellana. 2009. Religion and Mediation: The Role of Faith-Based Actors in International Conflict Resolution. International Negotiation 14: 175-204. [CrossRef]

Blanchard, Lauren Ploch. 2016. Nigeria's Boko Haram: Frequently Asked Questions, Congressional Research Service Report. Washington: Congressional Research Service. Available online: www.crs.gov (accessed on 1 April 2016).

Boukar, Bakari. 2014. Christian-Muslim Relations on Pere Plain: Challenges for the Evangelical Lutheran Church in Cameroon. MA thesis, School and Mission of Theology of Stavanger, Stavanger Area, Norway.

Chapman, Colin. 2007. Christian Responses to Islam, Islamism and 'Islamic Terrorism'. Cambridge Papers 16: 1-6.

Christian Institute. 2015. Extremism against Christians. Available online: www.christian.org.uk (accessed on 4 March 2016).

Crossmap Christian News. 2015. Cameroon's Churches Struggle to Cope with Boko Haram Spillover. Available online: http:/ / www.crossmap.com/news (accessed on 3 March 2016).

Djadi, Illia. 2014. Cameroon's Churches Struggle to Cope with Boko Haram Spillover. World Watch Monitor. Available online: https:/ / www.worldwatchmonitor.org/2014/09/cameroons-churches-struggle-to-copewith-boko-haram-spillover/ (accessed on 3 July 2017).

Dronen, Tomas Sundnes. 2013. Pentecostalism, Globalization, and Islam in Northern Cameroon: Megachurches in the Making? Leiden: Brill.

Esposito, John L. 2002. Unholy War: Terror in the Name of Islam. Oxford: Oxford University Press.

Fanso, Verkijika G. 1989. The Colonial and Post Colonial Periods. In Cameroon History for Secondary Schools and Colleges. London: Macmillan, vol. 2.

Fonge, Fuabeh. 2015. Conceptualizing the Trajectories and Proselytization of Islam in Africa. International Journal of Humanities and Social Sciences 5: 24-35.

Fox, Jonathan. 1999. Towards a Dynamic Theory of Ethno-Religious Conflict. Nations and Nationalism 5: 431-63. [CrossRef]

Goyek, Daga Robert. 2012. The State of Christian-Muslim Relations in Cameroon: Challenges Opportunities for Collaboration for Peace and Development. Paper presented at the Africa and Muslim Religious Leaders Conference on Peace and Development, Addis Abeba, Ethiopia, January 8-13; pp. 101-3.

Guibbaud, Pauline. 2014. BokoHaram: Le Nord-Cameroun dans la Tourmente? Available online: http:/ / www. grip.org/fr/node/1310 (accessed on 14 February 2016).

International Crisis Group. 2015. Cameroon: The Threat of Religious Radicalism. Africa Report No. 229; Brussels: International Crisis Group.

Juergensmeyer, Mark. 2003. Terror in the Mind of God: The Global Rise of Religious Violence. Santa Barbara: University of California Press.

Jumbam, Gerald Nyuykongmo. 2014. Nigeria and Boko Haram: Lessons for Cameroon. L'Effort Camerounais. Available online: http:/ / www.effortcamerounais.com (accessed on 23 February 2016). 
Kadayifci-Orellana, S. Ayse. 2013. Interreligious Dialogue and Peacebuilding. In The Wiley-Blackwell Companion to Inter-Religious Dialogue. Edited by Catherine Cornille. Hoboken: John Wiley \& Sons. Ltd., pp. 149-67.

Kah, Henry Kam. 2016. The Seleka Insurgency and Insecurity in the Central African Republic, 2012-2014. African Journal for the Prevention and Combating of Terrorism 5: 35-69.

Kah, Henry Kam. 2014. Anti-Balaka/Seleka, 'Religionisation' and Separatism in the History of the Central African Republic. Conflict Studies Quarterly 9: 30-48.

Kate, Zebiri. 1997. Muslims and Christians Face to Face. Oxford: One World Publications.

Lang, Michael Kpughe. 2015. Religious Diversity in Cameroon: A Historical Survey. African Humanities Review 1: 55-71.

Last, Murray. 2014. From Dissent to Dissidence: The Genesis and Development of Reformist Islamist Groups in Northern Nigeria. In Sects and Social Disorder: Muslim Identities and Conflict in Northern Nigeria. Edited by Abdul Raufu Mustapha. Woodbridge: James Curray, pp. 18-53.

Mark, Monica. 2012. Nigerian Islamist group's leader claims to be at war with Christians. Guardian. Available online: http:/ / www.theguardian.com/world/2012/jan/11 (accessed on 10 January 2014).

Messina, Jean-Paul, and Jaap Slageren. 2005. Histoire du Christianisme au Cameroun: Des Origines a Nos Jours. Paris et Yaoundé: Editions Karthala et Editions Cle.

Ngoh, Victor Julius. 1996. History of Cameroon Since 1800. Limbe: Presbook.

Njeuma, Martin Z. 1978. Fulani Hegemony in Yola (Old Adamawa) 1809-1902. Yaounde: CEPER.

Njeuma, Martin Z. 2000. Regionalisation and Creation of a 'Northern Cameroon' Identity. Available online: https:/ / www.oslo2000.uio.no/program/papers/s9-njeuma.pdf (accessed on 10 May 2015).

Ogochukwu, Ezema Obianuju. 2013. The Socio-Economic Implications of the Boko Haram Insurgence in Nigeria: 2009-2013. Bachelor of Science dissertation, Political Science, Caritas University, Enugu, Nigeria.

Onuoha, Freedom C. 2014. A Danger not to Nigeria Alone: Boko Harams Transnational Reach and Regional Responses. Abuja: Friedrich-Ebert-Stiftung. Available online: www.fes-westafrica.org/abuja (accessed on 29 April 2016).

Reeve, Richard. 2014. The Internationalization of Nigeria's Boko Haram Campaign. Oxford: Oxford Research Group Special Briefing.

Rt. Rev. Samuel Forba Fonki. 2015. Induction Sermon as PCC Moderator. Available online: http:/ /www.pcc.cm/ downloads/Induction\%20Sermon\%20Moderator.pdf (accessed on 3 July 2017).

Shekau, Abubakar. 2012. Shekau Abubakar's Video Message. Available online: http:/ /saharareporters.com/ 2012/01/12 (accessed on 23 March 2014).

Schilder, Kees. 1993. Local Rulers in North Cameroon: The Interplay of Politics and Conversion. Africa Focus 9: 43-72.

Thurston, Alex. 2016. The Disease is Unbelief: Boko Haram's Religious and Political Worldview. The Brookings Project on U. S. Relations with the Islamic World 22. Available online: www.brookings.edu (accessed on 27 February 2016).

Voll, John O. 2015. Boko Haram: Religion and Violence in the 21st Century. Religions 6: 1182-202. Available online: www.mdpi.com/journal/religions (accessed on 8 June 2017).

Walker, Andrew. 2012. What Is Boko Haram? Special Report for the United States Institute of Peace. Available online: www.usip.org (accessed on 20 January 2016).

James K. Wellman, ed. 2007. Belief and Bloodshed: Religion and Violence across Time and Tradition. New York: Rowman \& Littlefield Publishers, INC.

World Watch Monitor. 2015. Multifaith Gathering in Mora on Boko Haram. Available online: https://www. worldwatchmonitor.org (accessed on 26 February 2016).

(C) 2017 by the author. Licensee MDPI, Basel, Switzerland. This article is an open access article distributed under the terms and conditions of the Creative Commons Attribution (CC BY) license (http://creativecommons.org/licenses/by/4.0/). 